Tailor Made Concrete Structures - Walraven \& Stoelhorst (eds)

C 2008 Taylor \& Francis Group, London, ISBN 978-0-415-47535-8

\title{
Shear strength in one- and two-way slabs according to the Critical Shear Crack Theory
}

\author{
A. Muttoni \& M. Fernández Ruiz \\ Ecole Polytechnique Fédérale de Lausanne, Lausanne, Switzerland
}

\begin{abstract}
Currently, there is no generally-accepted theory giving a physical explanation of the shear strength in one- and two-way slabs. Furthermore, for members without transverse reinforcement, shear strength is estimated in most codes of practice following empirical or semi-empirical approaches. In this paper, the fundamentals of the Critical Shear Crack Theory (CSCT) are introduced. This theory, based on a mechanical model, is shown to provide a unified approach for one- and two-way shear in slabs, leading to simple design expressions for estimating the strength and deformation capacity of such members. The paper also details a code-like formulation based on this theory and developed for the Swiss code for structural concrete. Comparisons of the theory to a wide range of test data are finally presented.
\end{abstract}

\section{INTRODUCTION}

Shear has been investigated in structural concrete from its early developments (Ritter 1899, Mörsch 1908) with theoretical and experimental works covering both one-way shear (Fig. 1a) and two-way shear (also known as punching shear, Fig. 1b).

With respect to beams and one-way slabs with transverse reinforcement, several consistent approaches based on the theory of plasticity as strut-and-tie models (Schlaich et al. 1987) or stress fields (Muttoni et al. 1997) have been successfully applied. Also, theories accounting for compatibility conditions as the Modified Compression Field Theory (MCFT, Vecchio and Collins 1986) or the fixed-angle softened-truss model (Pang and Hsu 1996) can also be applied to such members giving accurate estimates of their strength and deformation capacity. On the other hand, scanty rational approaches have been developed in other fields concerning shear:

- With respect to beams and one-way slabs without transverse reinforcement, currently most design approaches are based on empirical models (ACI 2005 , Eurocode 22004 ). However, some physicallysound theories like the MCFT have been successfully applied to such members, opening a promising approach for the unified treatment of one-way shear in members with and without transverse reinforcement. Recently, a simplified form of the MCFT has been developed and introduced into the Canadian code for structural concrete CSA (2004). (a)

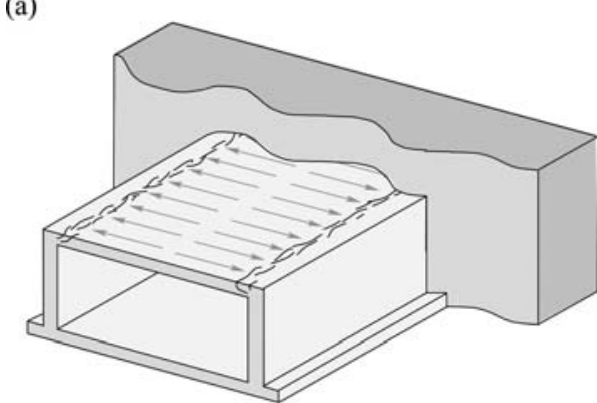

(b)

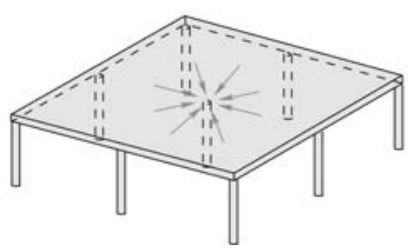

Figure 1. Shear in R/C slabs: (a) one-way shear developing in top slab of a cut-and-cover tunnel; and (b) two-way shear developing in a flat slab supported by columns.

- With respect to punching of slabs without transverse reinforcement, the first rational approach developed with a certain success was that of Kinnunen and Nylander (1960), which inspired the work of other researchers (Hallgren, 1996, Broms, 2006). However, most design approaches are still based 
on empirical formulations (ACI 2005, Eurocode 2 2004). Also, none of the aforementioned theories for beams and one-way slabs (Vecchio and Collins 1986, Pang and Hsu 1996) have yet successfully been applied to the problem of punching shear.

- With respect to punching of slabs with transverse reinforcement, most design approaches are based on the empirical formulations adopted for members without transverse reinforcement (reducing the concrete contribution) and adding a contribution of the punching shear reinforcement (ACI 2005, Eurocode 2 2004). The design of such members relies thus mainly on empirical formulations. However, some efforts are currently being devoted to the development of physically-sound models for dimensioning of such members (Birkle, 2004).

In this paper, the theoretical ground of the Critical Shear Crack Theory (CSCT) is presented and discussed. The CSCT is a theory based on a mechanical model that allows treating in a unified manner both shear and punching-shear problems. The application of the CSCT to the design of members without transverse reinforcement (one-way and two-way slabs) is finally presented in this paper, introducing the implementation of this theory into the Swiss code SIA 262 (2003).

The CSCT is also applicable to shear-reinforced members (Fernández Ruiz and Muttoni 2007). However, details on this topic will not be treated within this paper.

\section{HISTORICAL DEVELOPMENT OF THE CRITICAL SHEAR CRACK THEORY}

The basic principles of the critical shear crack theory were introduced for the first time in the Draft code proposal (Muttoni, 1985) of the Swiss code for structural concrete SIA 162 (1993). An experimental campaign followed (Muttoni and Thürlimann, 1986), where the role of the crack width in the shear cracks developing through the web of beams was investigated. Two works (Muttoni 1989 and Muttoni and Schwartz 1991) summarized the main theoretical findings, and were the basis of the approach for members without transverse reinforcement in the Swiss code for structural concrete SIA 162 in 1993. Further improvements of the theory for shear in one-way slabs and punching shear (Muttoni 2003a, 2003b and 2003c) were recently included in the new version of the Swiss code for structural concrete (SIA 262, 2003), which can be considered to be fully based on this theory for the shear design of members without stirrups.

Currently, the theory continues to be improved and extended. New developments account for the shear strength in beams (Vaz Rodrigues 2007) and slabs
(Guandalini 2005) with plastic strains, the position of the control section for beams under distributed loading (Muttoni 2003b, Muttoni and Fernández Ruiz 2007), analytical formulations of load-rotation relationships for axysimmetric slabs (Muttoni 2007) and the strength of slabs with shear reinforcement (Fernández Ruiz and Muttoni 2007). Also, several experimental campaigns have recently been performed (Guandalini and Muttoni 2004, Vaz Rodrigues 2004, Vaz Rodrigues 2006, Tassinari et al. 2007, Guidotti et al. 2007) allowing to verify several phenomena predicted by the CSCT.

\section{THEORETICAL APPROACH OF THE CSCT}

The critical shear crack theory is based on the assumption that the shear strength in members without transverse reinforcement, traditionally correlated to the square root of the concrete compressive strength after the works of Moody (1954), is governed by the width and by the roughness of a shear crack which develops through the inclined compression strut carrying shear (Muttoni 2007, Muttoni and Fernández Ruiz 2007), see Figure 2.

This dependence is expressed as follows:

$\frac{V_{R}}{b_{0} \cdot d}=\sqrt{f_{c}} \cdot f\left(w, d_{g}\right)$

where $V_{R}$ is the shear strength, $b_{0}$ is a control perimeter (equal to the width of the member $(b)$ in beams and set at $d / 2$ of the border of a column for punching shear), $d$ is the effective depth of the member, $f_{c}$ is the compressive strength of the concrete, $w$ is the width of the shear critical crack and $d_{g}$ is the maximum size
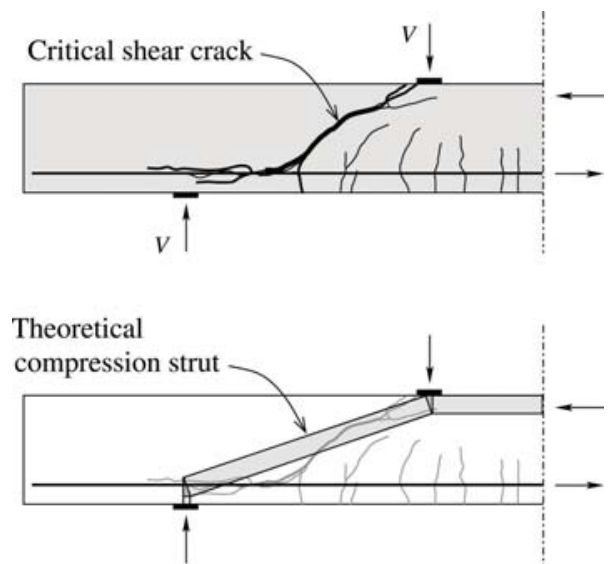

Figure 2. Critical shear crack developing through the shear-carrying compression strut in a simply supported beam. 
of the aggregate (accounting for the roughness of the lips of the cracks).

According to the CSCT, the width of the shear critical crack $(w)$ in one way-slabs is assumed to be proportional to the strain in a control depth $(\varepsilon$, at $0.6 d$ from the compression face) times the effective depth of the member (see Fig. 3a):

$w \propto \varepsilon \cdot d$ (One - way slabs)

In two-way slabs, the width of the critical shear crack is assumed proportional to the slab rotation $(\psi)$ times the effective depth of the member (see Fig. 3b):

$w \propto \psi \cdot d$ (Two - way slabs)

Based on these assumptions, the following failure criteria (Muttoni 2003a) have been derived for members without stirrups:

$\frac{V_{R}}{b_{0} \cdot d \cdot \sqrt{f_{c}}}=\frac{1 / 3}{1+120 \frac{\varepsilon \cdot d}{d_{\mathrm{g} 0}+d_{g}}}$

(One - way slabs [SI - units : MPa, mm])

$\frac{V_{R}}{b_{0} \cdot d \cdot \sqrt{f_{c}}}=\frac{3 / 4}{1+15 \frac{\psi \cdot d}{d_{g 0}+d_{g}}}$

(Two - way slabs [SI - units : MPa, mm])

where $d_{g 0}$ is a reference aggregate size equal to $16 \mathrm{~mm}$.

(a)

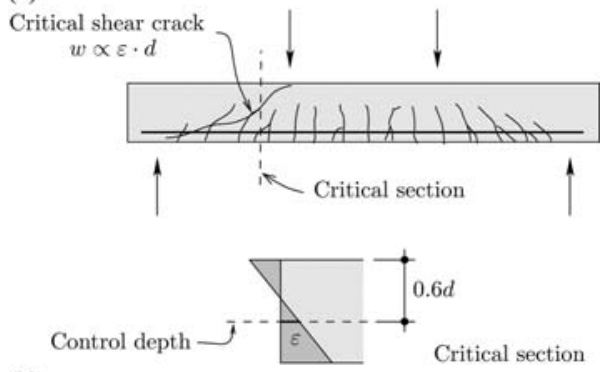

(b)

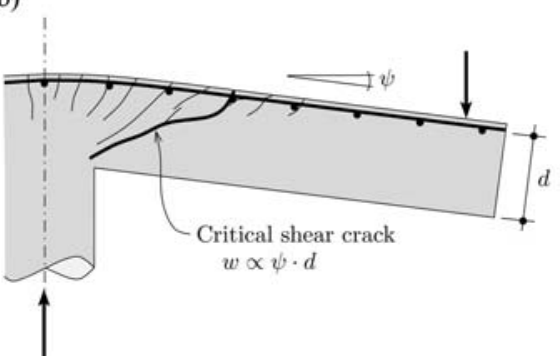

Figure 3. Correlation of the critical shear crack width for: (a) beams and one-way slabs; and (b) slabs.
A comparison of the failure criteria proposed by the CSCT to the test results of 285 beams (Muttoni and Fernández Ruiz 2007) and 99 slabs (Muttoni 2007) are given in Figure 4. The comparison shows an excellent agreement between theory and experiments, with a very small coefficient of variation. Such results are better than those obtained with some codes of practice (ACI 2005, Eurocode 22004 ) as shown in Muttoni and Fernández Ruiz (2007) and Muttoni (2007).

(a)

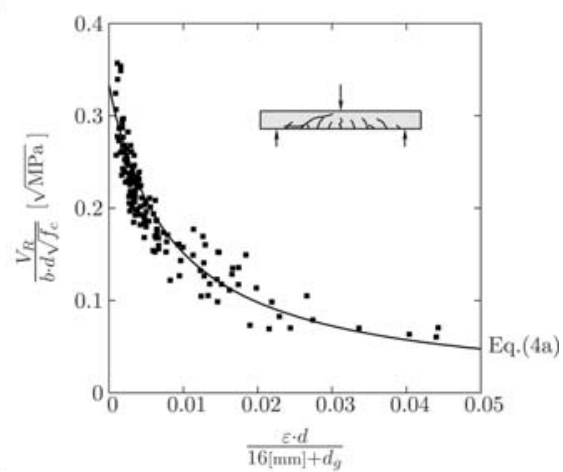

(b)

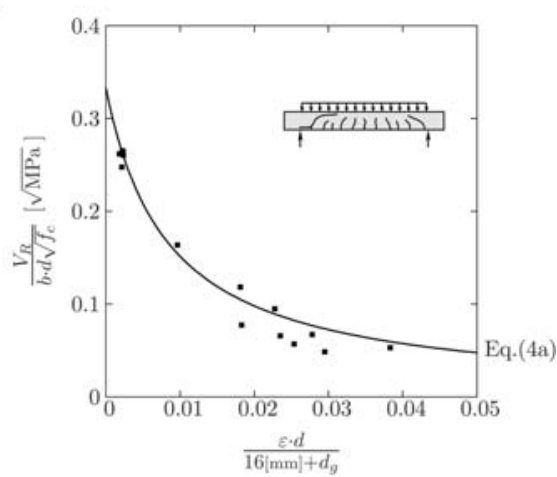

(c)

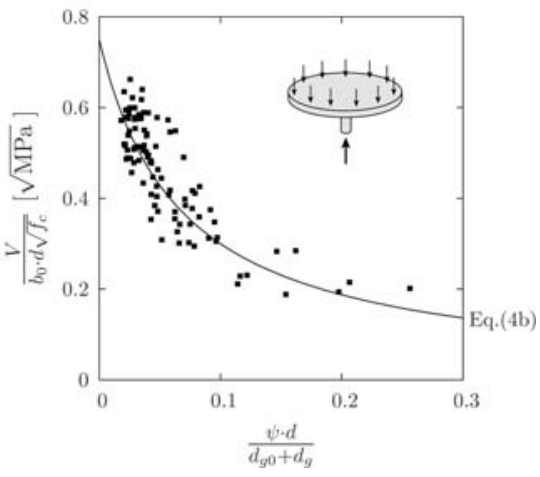

Figure 4. Comparison of the failure criteria (Eq. (4)) to test results of members without transverse reinforcement: $(\mathrm{a}, \mathrm{b})$ beams subjected to point load and uniform loading respectively; and (c) slabs subjected to punching shear. 
It can be noted that the deformation capacity at ultimate can also be obtained from the failure criteria (expressed by the rotation of the slab for punching and by the strains in the critical section for beams).

\section{CODE-LIKE FORMULATION}

Adopting some reasonable assumptions (Muttoni and Fernández Ruiz 2007, Muttoni 2007), the previous failure criteria can be used to derive design formulae for members without transverse reinforcement. For beams in shear (Muttoni and Fernández Ruiz 2007), the following design formula results:

$$
\frac{V_{R d}}{b_{0} \cdot d \cdot \sqrt{f_{c k}}}=\frac{0.2}{1+0.0022 \cdot d \cdot \frac{m_{E d}}{m_{R d}}}
$$

[SI - units : MPa, mm]

where $m_{E d}$ is the design bending moment applied at the control section and $m_{R d}$ is the design flexural strength of the section. Since $m_{E d}$ depends on the applied shear, the shear strength $\left(V_{R d}\right)$ can be obtained explicitly for instance in members subjected to point loads by solving the resulting quadratic expression. A comparison (Muttoni and Fernández Ruiz 2007) of Eq. (5) to the test results shown in Figures 4a,b leads to an average value of the ratio $V_{\text {test }} / V_{C S C T}=1.09$ with a coefficient of variation of 0.11 .

For punching shear, the strength of a slab can be checked using the following design formula:

$$
\frac{V_{R d}}{b_{0} \cdot d \cdot \sqrt{f_{c k}}}=\frac{0.2}{0.45+0.135 \cdot L \cdot\left(\frac{m_{0 d}}{m_{R d}}\right)^{3 / 2}}
$$

[SI - units : MPa, mm]

where $L$ is the span of the slab and $m_{0 d}$ is a reference moment depending on the type and boundary conditions of the column (inner column $m_{0 d}=V_{d} / 8$; border column $m_{0 d}=V_{d} / 4$ or edge column $m_{0 d}=V_{d} / 2$ ). A comparison (Muttoni 2007) of Eq. (6) to the test results shown in Figure 4c leads to an average value of the ratio $V_{\text {test }} / V_{C S C T}=1.07$ with a coefficient of variation of 0.09 .

More details on the implementation of the CSCT to the Swiss code for structural concrete SIA 262 (2003) can be found in references (Muttoni 2003a,b,c).

\section{CONCLUSIONS}

The main conclusions of this paper are:

1. The Critical Crack Width Theory (CSCT) provides a consistent approach to study the strength of members subjected to one-way shear or two-way shear (punching).

2. The CSCT can be applied to both members with and without shear reinforcement.

3. Accurate results are obtained with the CSCT when compared to test results with a very small coefficient of variation.

4. Design formulae of the failure criteria, together with some reasonable assumptions for the loaddeformation relationship of the members, allow to implement the theory in a code-friendly manner.

5. The current Swiss code for structural concrete SIA 262 (2003) for members without transverse reinforcement is fully based on the design formulations of the CSCT.

\section{NOTATION}

The following symbols are used in the paper:

$E_{S} \quad=$ modulus of elasticity of reinforcement

$L \quad=$ main span of a slab system

$V \quad=$ shear force

$V_{d} \quad=$ factored shear force

$V_{R} \quad=$ nominal punching shear strength

$V_{R d}=$ design punching shear strength

$V_{C S C T}=$ shear strength according to the CSCT

$V_{\text {test }}=$ measured shear strength

$b_{0} \quad=$ perimeter of the critical section for punching shear

$b \quad=$ width of a beam

d = distance from extreme compression fibre to the centroid of the longitudinal tensile reinforcement

$d_{g} \quad=$ maximum diameter of the aggregate

$d_{g 0} \quad=$ reference aggregate size $(16 \mathrm{~mm}$ (0.63 in))

$f_{c} \quad=$ average compressive strength of concrete (cylinder)

$f_{c k}=$ design value of the compressive strength of concrete (cylinder)

$f_{y d}=$ factored value of the yield strength of reinforcement

$m_{E d}=$ applied moment capacity at section of control

$m_{0 d} \quad=$ reference moment depending on the type of the column

$m_{R d}=$ design moment capacity per unit width

$w \quad=$ width of the critical shear crack

$\varepsilon \quad=$ reference strain in beams taken at $0.6 \cdot d$

from the compression face

$\psi \quad=$ rotation of slab outside the column region

\section{REFERENCES}

Ritter, W. 1899. The Hennebique construction method (in German, "Die Bauweise Hennebique"), Scweizerische Bauzeitung, XXXIII, No 7, pp. 41-61. 
Mörsch, E. 1908. Reinforced concrete construction, theory and application (in German, "Der Eisenbetonbau, seine Theorie und Andwendung"), 3rd Edition, Verlag von Konrad Wittwer, 376 p.

Schlaich, J., Schäfer, K. And Jennewein, M. 1987. Toward a consistent design of structural concrete, Prestressed Concrete Institute Journal, May-June, pp. 75-150.

Muttoni, A., Schwartz, J., And Thürlimann, B. 1997. Design of concrete structures with stress fields, Birkhaüser, Basel, Boston and Berlin, Switzerland, $145 \mathrm{p}$.

Vecchio F. J., Collins M. P. 1986. The Modified CompressionField theory for Reinforced Concrete Elements Subjected to Shear, ACI Journal, Vol. 83, No. 2, pp. 219-231.

Pang, X-B, And Hsu, T. T. C. 1996. Fixed Angle Softened Truss Model for Reinforced Concrete, ACI Structural Journal, Vol. 93(2), pp. 197-207.

ACI, Building Code Requirements for Structural Concrete (ACI318-05) and Commentary (ACI 318R-05), 2005. American Concrete Institute, Farmington Hills, Mich., $430 \mathrm{p}$.

Eurocode 2 2004. Design of concrete structures - Part 1-1: General rules and rules for buildings, CEN, EN 1992-1-1, Brussels, Belgium, 225 p.

CSA Committee A23.3 2004. Design of Concrete Structures (CSA A23.3-04), Canadian Standards Association, Mississauga, $214 \mathrm{p}$.

Kinnunen S., Nylander H. 1960. Punching of Concrete Slabs Without Shear Reinforcement, Transactions of the Royal Institute of Technology, $\mathrm{N}^{\mathrm{o}}$ 158, Stockholm, Sweden, $112 \mathrm{p}$.

Hallgren M. 1996. Punching Shear Capacity of Reinforced High Strength Concrete Slabs, Doctoral thesis, Royal Institute of Technology, Stockholm, Sweden, $206 \mathrm{p}$.

Broms C. E. 2006. Concrete flat slabs and footings: Design method for punching and detailing for ductility, Royal Institute of Technology, Stockholm, Sweden, $114 \mathrm{p}$.

Birkle, g. 2004. Punching of Flat Slabs: The Influence of Slab Thickness and Stud Layout, Doctoral thesis, University of Calgary, Calgary, Alberta, Canada, $152 \mathrm{p}$.

SIA 2003. Code 262 for Concrete Structures, Swiss Society of Engineers and Architects, Zürich, Switzerland, $94 \mathrm{p}$.

Muttoni, A. 1985. Punching shear - Draft code proposal, SIA 162, Working Group 5, Swiss Society of Engineers and Architects, Zürich, 15 p.

SIA, Code 162 for Concrete Structures, Swiss Society of Engineers and Architects, Zürich, Switzerland, 1993, 86 p.

Muttoni, A., Thürlimann, B. 1986. Shear tests on beams and slabs without shear reinforcement (in German, "Schubversuche an Balken und Flachdecken ohne Schubbewehrung"), Institut für Baustatik und Konstruktion, ETH Zürich, 12 p., this report can be downloaded from: http://is-beton.epfl.ch/Publications/198x/Muttoni86.pdf).

Muttoni, A. 1989. The applicability of the theory of plasticity in the design of reinforced concrete (in German, "Die Andwendbarkeit der Plastizitätstheorie in der Bemessung von Stahlbeton"), Institut für Baustatik und Konstruktion, Report Nr. 176, ETH Zürich, 159 p.

Muttoni A., Schwartz J. 1991. Behaviour of Beams and Punching in Slabs without Shear Reinforcement, IABSE Colloquium Stuttgart, Vol. 62, IABSE, Zurich, Switzerland, pp. 703-708.

Muttoni, A. 2003a. Shear and punching strength of slabs without shear reinforcement, (in German, "Schubfestigkeit und Durchstanzen von Platten ohne Querkraftbewehrung”), Beton- und Stahlbetonbau, Vol. 98, pp. 74-84.

Muttoni, A. 2003b. Members without shear reinforcement, (in French, "Elements sans armature d'effort tranchant"), Introduction to the Swiss code SIA 262, Documentation D 0182, Swiss Society of Engineers and Architects, Zürich, pp. $47-55$.

Muttoni, A. 2003c. Punching shear, (in French, "Poinconnement"), Introduction to the Swiss code SIA 262, Documentation D 0182, Swiss Society of Engineers and Architects, Zürich, pp. 57-66.

Vaz Rodrigues, R. 2007. Shear strength of reinforced concrete bridge deck slabs, Doctoral thesis, École Polytechnique Fédérale de Lausanne, No. 3739, Lausanne, Switzerland, $114 \mathrm{p}$.

Guandalini S. 2005. Symmetric Punching in R/C slabs (in French: "Poinçonnement symétrique des dalles en béton armé"), Doctoral thesis, École Polytechnique Fédérale de Lausanne, No. 3380, Lausanne, Switzerland, 289 p.

Muttoni, A., Fernández Ruiz, M. 2007. Shear strength of members without transverse reinforcement as a function of the critical shear crack width, ACI Structural Journal, Farmington Hills, Mich., accepted for publication, 2007

Muttoni, A. 2007 Punching shear strength of reinforced concrete slabs without transverse reinforcement, $A C I$ Structural Journal, Farmington Hills, Mich., accepted for publication, 2007

Fernández Ruiz, M., Muttoni, A. 2007 Punching shear strength of reinforced concrete slabs with transverse reinforcement, ACI Structural Journal, Farmington Hills, Mich., submitted for publication, 2007

Guandalini S., Muttoni A. 2004. Symmetric punching tests on reinforced concrete slabs without shear reinforcement (in French: "Essais de poinçonnement symétrique des dalles en béton armé sans armature à l'effort tranchant"), Test report, École Polytechnique Fédérale de Lausanne, Lausanne, Switzerland, $78 \mathrm{p}$.

Vaz Rodrigues, R. 2004. Shear strength without stirrups after yielding of RC slab strips (in Frech: "Influence des déformations plastiques de l'armature de flexion sur la résistance à l'effort tranchant des poutres sans étriers"), Test Report, École Polytechnique Fédérale de Lausanne, Lausanne, Switzerland, 2004, 77 p.

Vaz Rodrigues, R. 2006. Large scale tests on reinforced concrete bridge deck slabs, Test Report, École Polytechnique Fédérale de Lausanne, Lausanne, Switzerland, 67 p.

Tassinari, L., Fernández Ruiz, M., Muttoni, A. 2007. Influence of the slenderness of $\mathrm{R} / \mathrm{C}$ slabs in the punching shear strength, (in French: "Influence de l'élancement de dalles en béton armé sur sa résistance au poinçonnement"), Test Report, École Polytechnique Fédérale de Lausanne, Lausanne, Switzerland, 28 p.

Guidotti, R., Fernández Ruiz, M., Muttoni, A. 2007. Influence of column forces in the punching shear strength of $\mathrm{R} / \mathrm{C}$ slabs, (in French: "Influence de l'effort normal de colonnes sur la résistance au poinçonnement de dalles en béton armé"), Test Report, École Polytechnique Fédérale de Lausanne, Lausanne, Switzerland, 38 p.

Moody, K. G., Viest, M., Elstner, R. C., Hognestad, E. 1954. "Shear strength of reinforced concrete beams Part 1. Tests of simple beams", ACI Journal, Vol. 26(4), pp. 317-332. 
